\title{
Natural orifice transluminal endoscopic surgery: A transtracheal approach for the thoracic cavity in a live canine model
}

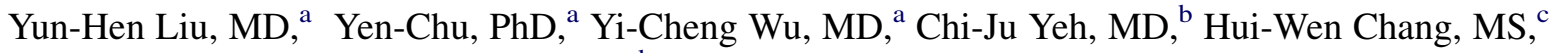 \\ Po-Jen Ko, MD, ${ }^{a}$ and Hui-Ping Liu, MD $^{\mathrm{d}}$
}

Background: The present study aimed to evaluate the performance of transtracheal thoracic exploration and pericardial window creation in a canine survival model.

\begin{abstract}
Methods: Transthoracic exploration was performed in $14 \mathrm{dogs}$. Under general anesthesia, after an incision in the right lateral wall of the middle-lower portion of the trachea was made, a 9-mm metal tube was advanced into the thoracic cavity. For thoracic cavity exploration and pericardial window creation, a flexible bronchoscope was introduced through the metal tube into the thoracic cavity. After thoracoscopy, a Dumon stent (Novatech, Grasse, France) was used to cover the tracheal incision site and facilitate healing. Animals were evaluated by endoscopy 1 and 2 weeks later. Animals were humanely killed, and necropsy was performed 2 weeks after the transtracheal natural orifice transluminal endoscopic surgery.
\end{abstract}

Results: Fourteen dogs underwent transtracheal thoracic exploration lasting for an average of 110 minutes (range, 80-150), with 3 perioperative deaths. At 2 weeks after pericardial window creation, endoscopy revealed normal healing of the tracheal incision sites in all 11 surviving animals. Necropsy on the 11 animals at 2 weeks showed 9 adhesions around the pericardial window and 5 adhesions around the tracheal incision region. No mediastinitis or abscesses could be identified.

Conclusions: Transtracheal thoracic exploration is technically feasible. Increasing surgical experience together with improvement in endoscopic techniques will further facilitate the development of natural orifice transluminal endoscopic surgery for thoracic diseases. (J Thorac Cardiovasc Surg 2011;141:1223-30)

Video clip is available online.

Since its development by Kalloo and associates ${ }^{1}$ in 2004 , there have been prolific studies on natural orifice transluminal endoscopic surgery (NOTES). These studies have included transluminal liver biopsy, lung biopsy, fallopian tubal ligation, cholecystectomy, gastrojejunostomy, oophorectomy, and hysterectomy.

With regard to intraluminal access to the body cavity, various techniques, including transgastric, transtracheal, and transrectal approaches, have been described. Because of

\footnotetext{
From the Laboratory Animal Center, ${ }^{\mathrm{a}}$ Department of Surgery, and the Department of Pathology, Chang Gung Memorial Hospital, Linko; Chang Gung University, ${ }^{b}$ Taoyuan, Taiwan; the Department of Pathology and Laboratory Medicine, ${ }^{\mathrm{c}}$ Taipei Medical University, Taipei, Taiwan; and the Department of Surgery, ${ }^{\mathrm{d}}$ Benq Medical Center, Nanjing, China.

This work was supported by the Chang Gung Memorial Hospital, Taiwan (Contract No. CMRPG-371472).

Disclosures: Authors have nothing to disclose with regard to commercial support. Received for publication July 29, 2010; revisions received Oct 18, 2010; accepted for publication Nov 4, 2010; available ahead of print Jan 31, 2011.

Address for reprints: Hui-Ping Liu, MD, Department of Surgery, Benq Medical Center, Nanjing, China, 71 Hexi Ave, Jianye District, Nanjing, Jiangsu (E-mail: foreverairmail@gmail.com).

$0022-5223 / \$ 36.00$

Copyright (C) 2011 by The American Association for Thoracic Surgery

doi:10.1016/j.jtcvs.2010.11.011
}

the great challenges of the NOTES approach to the thoracic cavity, only limited data are available on the use of NOTES in the evaluation and treatment of thoracic diseases. ${ }^{2-4}$

$\mathrm{We}^{5,6}$ have previously reported the feasibility of performing a pleural and surgical lung biopsy using a completely transtracheal NOTES technique. The present study aimed to investigate the performance of using transtracheal NOTES to perform transtracheal thoracic exploration (TTEP) and pericardial window creation as well as to determine the safety of using Dumon stents (Novatech, Grasse, France) for treating tracheal incisions after transtracheal thoracic surgery.

\section{MATERIAL AND METHODS}

The use of animals for study was approved by the Ethics Committee on Animal Research of the Chang Gung Memorial Hospital. Studies were conducted in an animal research laboratory. Fourteen dogs (weight: 7-9 kg) were used in the present experiment. Preanesthetic sedation consisted of ketamine $(5 \mathrm{mg} / \mathrm{kg})$ and xylazine $\mathrm{HCl}(10 \mathrm{mg} / \mathrm{kg})$. The animals underwent endotracheal intubation, and general anesthesia was maintained with continuous inhalation of isoflurane, supplemented with bolus application of xylazine $\mathrm{HCl}(5 \mathrm{mg} / \mathrm{kg}$ intravenous). Before TTEP was performed, an antibiotic ( $250 \mathrm{mg}$ cefazoline) was administered to all animals.

During the early period of this study, ventilation was maintained with conventional jet ventilation, with the animal in the supine position. During the later period of our experiment, ventilation was shifted to mechanical volume-controlled ventilation using a homemade long endotracheal tube (Figure 1, Video 1); the endotracheal tube was introduced into the lower trachea, with the cuff located approximately $1 \mathrm{~cm}$ above the carina. 


\section{Abbreviations and Acronyms \\ $\mathrm{CBC}=$ complete blood count \\ $\mathrm{CRP}=\mathrm{C}$-reactive protein \\ NOTES $=$ natural orifice transluminal endoscopic surgery \\ TTEP $=$ transtracheal thoracic exploration}

were noted in the 11 animals that survived the 2-week postprocedure period.

\section{Tracheal Incision and Management}

In 12 animals, the procedure was performed using a single tracheal incision; 2 other animals required 2 tracheal incisions to complete the TTEP. Of the 12 animals that survived the immediate postprocedure period, 10 had 1 stent for tracheal incision closure, and 2 required 2 stents each to seal the tracheal entrance. The incidence of air leakage was higher in animals with 2 tracheal incisions; both animals with 2 tracheal incisions had emphysema complications, and 1 of them even received 2 stents for tracheal closure. In contrast, no air leakage was evident in the other 10 animals with a single tracheal incision.

\section{Prophylactic Chest Tube Drainage}

From our previous experiences, chest tube drainage decreases the risks of intraoperative tension pneumothorax. ${ }^{5}$ In the present study, modification of the anesthesia technique using a homemade endotracheal tube created a platform on which NOTES could be performed in the thoracic cavity without pleural drainage. The intraoperative mortality was $0 \%(0 / 5)$ and $22.9 \%(2 / 9)$ in animals with and without pleural drainage, respectively. However, both animals died of complications (hemorrhage and cardiac arrest) that were not related to intraoperative tension pneumothorax.

\section{Physiologic Parameters}

A low-grade fever $\left(39.6^{\circ} \mathrm{C}\right)$ developed between 1 and 3 days after the procedure and returned to normal 7 days after the procedure in 3 animals. However, these 3 animals exhibited normal activity, had regular oral intake, showed no signs of illness, and survived for 2 weeks after the procedure. The postoperative respiratory rates (mean, 32 breaths/min; range, 22-42 breaths/min) were not significantly different from the baseline (10-32 breaths/min).

\section{Inflammatory Parameters}

The change in leukocytes (WBC, normal: 4.0-15.5 × 103 cells/L) in the animals is shown in Figure 5. The WBC increased above baseline in all 11 animals 1 day after the procedure and returned to baseline 3 days after the procedure in 9 animals. The WBC returned to baseline after 7 days in 10 animals. The CRP levels (normal $<5 \mathrm{mg} / \mathrm{dL}$ ) were significantly increased from baseline between days 1 and 7 after the procedure. The CRP levels returned to baseline in 7 of the 11 animals by 2 weeks after the operation (Figure 6)

\section{Complications}

Two animals died during the procedure (1 owing to cardiac arrest during electrocautery creation of a pericardial 

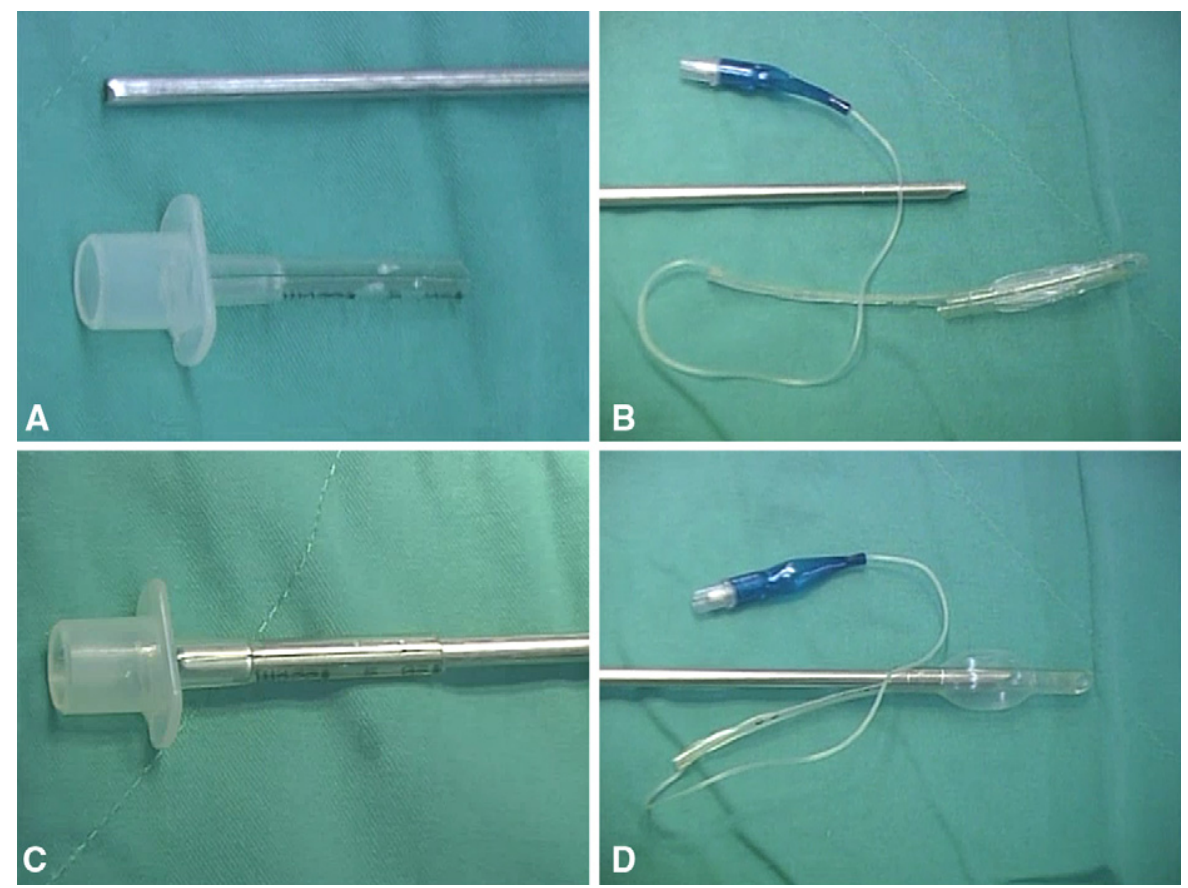

FIGURE 1. The homemade endotracheal tube.

window and 1 owing to hilar injury during creation of a tracheal entrance). Another animal had massive subcutaneous emphysema and died 5 hours after the operation. One animal was found to have subcutaneous emphysema over its right chest region 1 day after the procedure; this animal recovered well after postoperatively. Two other animals exhibited partial obstruction of the stent by granulation or increased airway secretion, and 1 of them had mild difficulty in breathing. Both animals were managed conservatively and were humanely killed 14 days after the operation.

\section{Endoscopic Follow-up}

Endoscopic follow-ups were performed at 1 week (when the stent was removed) and 2 weeks (when tracheal incision regions were evaluated) after the operation. Follow-up bronchoscopic examination at 2 weeks showed normal

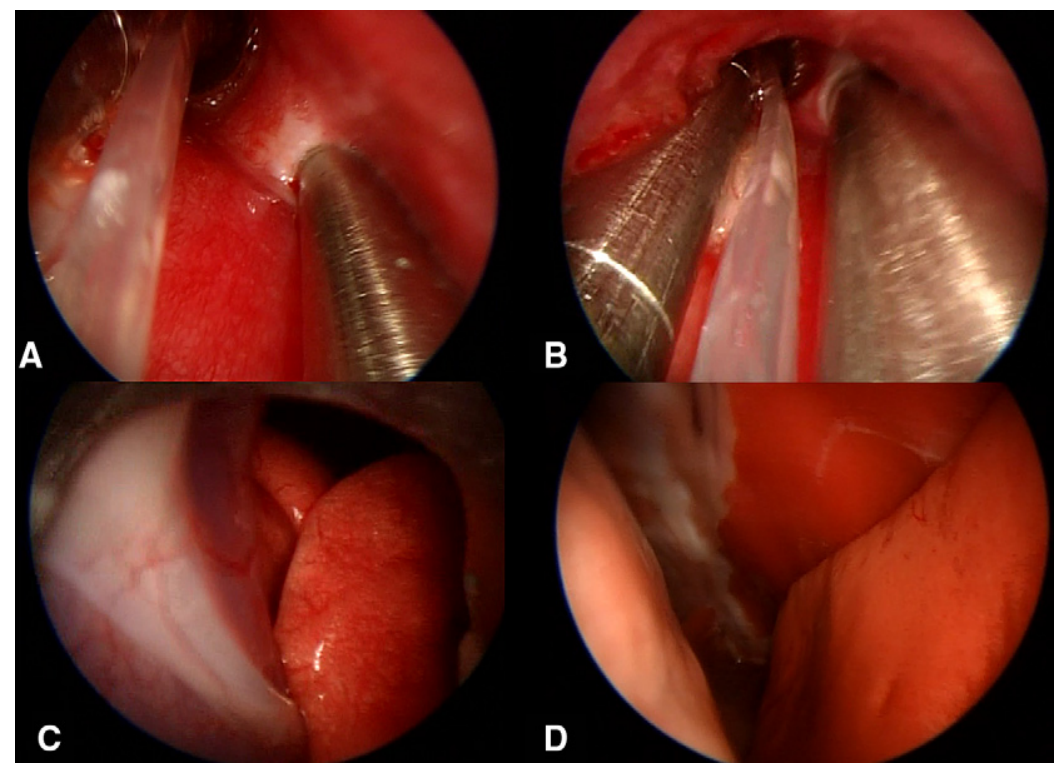

FIGURE 2. A, Tracheal wall incision created with a homemade metallic knife. B, The tracheal wall incision was created with a sequential dilating technique. $\mathrm{C}$ and $\mathrm{D}$, The costophrenic angle, chest wall, apex of the lung, and mediastinum were exposed after entering the thoracic cavity. 


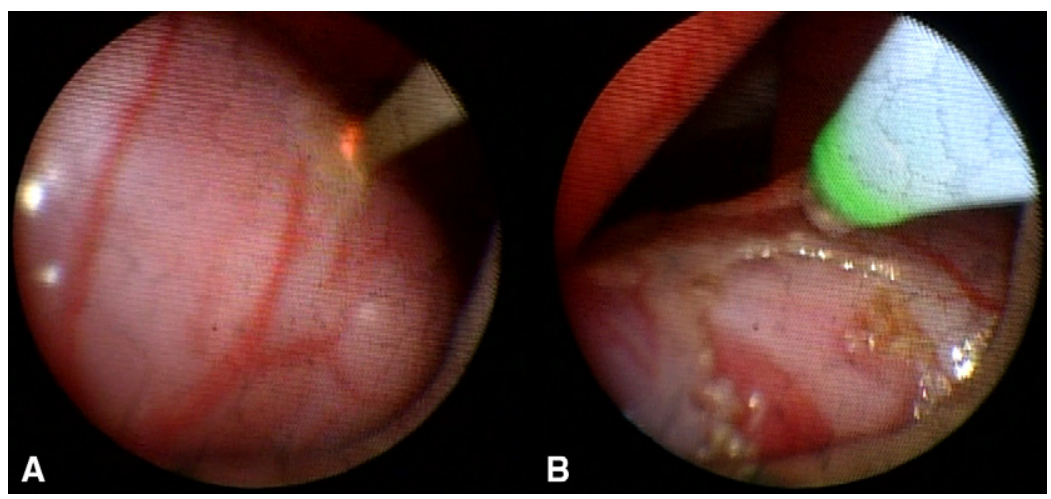

FIGURE 3. Pericardial window creation using a needle knife.

healing of tracheal incision sites in all 11 surviving animals. During bronchoscopic examination, 2 of 11 animals showed granulation over the proximal edge of the stent with partial obstruction of the airway lumen 1 week after the procedure. Removal of the airway stent resulted in improved airway patency during the 2-week postoperative examination.

\section{Necropsy Evaluation (Figure 7, Video 6)}

Autopsy was performed in 12 animals (11 that survived until 2 weeks after the operation and the 1 that had massive bleeding during creation of tracheal entrance). In the animal in which bleeding occurred during tracheal dilation, perforation over the superior-anterior wall of the pulmonary hilum was noted. During necropsy, 9 of 11 animals had pericardial adhesion around the pericardial window, and 5 of
11 animals had adhesion over the tracheal incision region. During necropsy, complete healing of the tracheal incision was observed in all 11 surviving animals. There were no signs of injury to intrathoracic vital organs, mediastinitis, or purulent collections inside the mediastinal cavity.

\section{Histologic Evaluation (Figure 8)}

Histopathologic evaluation of the tracheal incision region was performed in the 11 animals that survived 2 weeks after the operation. All specimens demonstrated a normal healing process, and no evidence of abscess formation over the tracheal incision region was observed. However, only 7 tracheal incision sites were confirmed by microscopic examination. With regard to microscopic findings, pure fibrosis was observed in 5 animals, fibrosis combined with

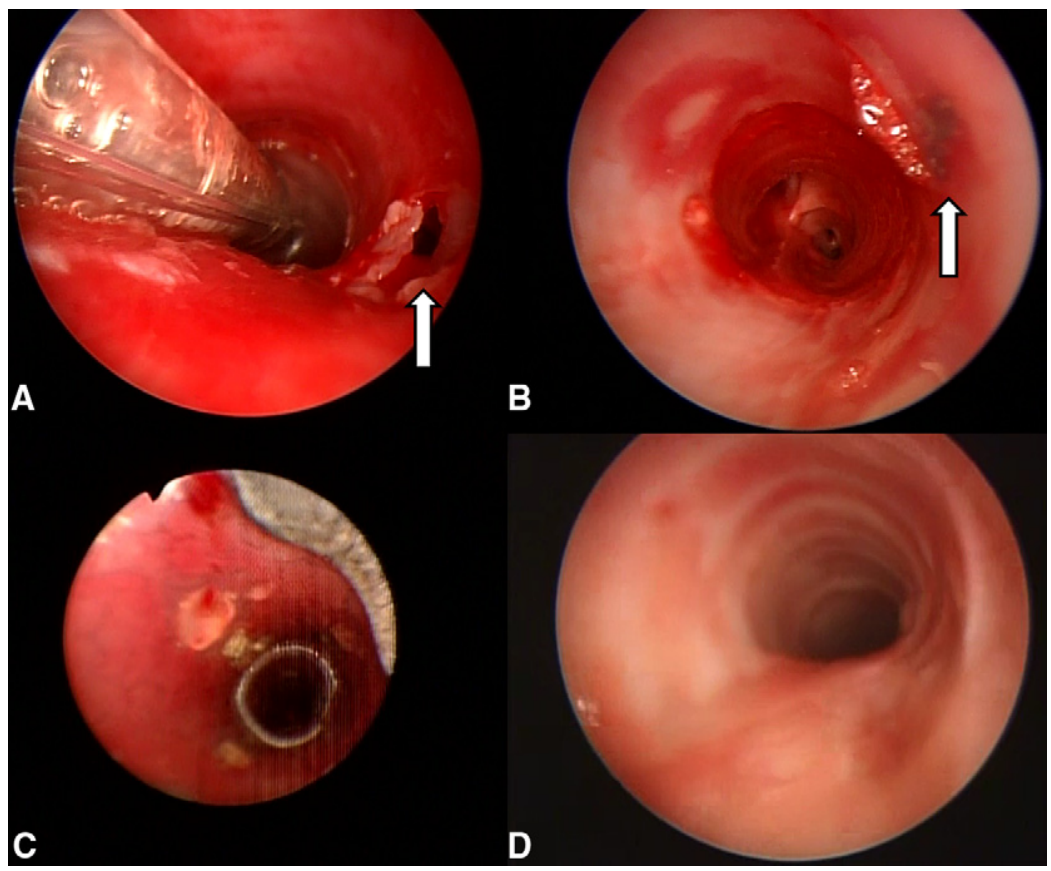

FIGURE 4. A, Tracheal wound after tracheal approach for thoracic evaluation. B, Complete tracheal wound closure with 1 silicone stent. C, Complete tracheal wound closure with 2 silicone stents. D, Fourteen days after stent removal. 
TABLE 1. Procedure characteristics and animal outcomes

\begin{tabular}{|c|c|c|c|c|c|c|c|c|c|c|}
\hline Animal & $\begin{array}{c}\text { Duration } \\
\text { (min) }\end{array}$ & $\begin{array}{l}\text { Tracheal } \\
\text { incision }\end{array}$ & $\begin{array}{l}\text { Stent } \\
(\mathbf{m m})\end{array}$ & $\begin{array}{c}\text { Pleural } \\
\text { drainage }\end{array}$ & $\begin{array}{c}\text { Periop } \\
\text { complication }\end{array}$ & $\begin{array}{c}\text { Granulation } \\
\text { after stenting }\end{array}$ & $\begin{array}{c}\text { Survival } \\
>2 \mathrm{wk}\end{array}$ & $\begin{array}{c}\text { Necropsy } \\
\text { finding }\end{array}$ & $\begin{array}{c}\text { Tracehal } \\
\text { incision } \\
\text { region (gross) }\end{array}$ & $\begin{array}{c}\text { Tracehal } \\
\text { incision region } \\
\text { (patho) }\end{array}$ \\
\hline Dog 1 & 130 & 1 & $12 \times 40$ & Yes & No & No & Yes & $\begin{array}{l}\text { Pericardial } \\
\text { adhesion }\end{array}$ & $\begin{array}{r}\text { Complete } \\
\text { healing }\end{array}$ & Fibrosis \\
\hline $\operatorname{Dog} 2$ & 140 & 1 & $11 \times 40$ & Yes & No & $\begin{array}{c}\text { Granulation with } \\
50 \% \text { airway } \\
\text { obstruction }\end{array}$ & Yes & $\begin{array}{l}\text { Tracheal } \\
\text { pericardial } \\
\text { adhesion }\end{array}$ & $\begin{array}{r}\text { Complete } \\
\text { healing }\end{array}$ & $\begin{array}{l}\text { Cartilage } \\
\text { regeneration }\end{array}$ \\
\hline Dog 3 & 140 & 1 & $12 \times 40$ & Yes & No & No & Yes & No & $\begin{array}{r}\text { Complete } \\
\text { healing }\end{array}$ & $\begin{array}{l}\text { Fibrosis } \\
\text { Inflamation }\end{array}$ \\
\hline $\operatorname{Dog} 4$ & 150 & 1 & $11 \times 40$ & Yes & No & $\begin{array}{c}\text { Granulation with } \\
40 \% \text { airway } \\
\text { obstruction }\end{array}$ & Yes & $\begin{array}{l}\text { Tracheal } \\
\text { pericardial } \\
\text { adhesion }\end{array}$ & $\begin{array}{r}\text { Complete } \\
\text { healing }\end{array}$ & Fibrosis \\
\hline $\operatorname{Dog} 5$ & 80 & 1 & $11 \times 40$ & Yes & No & No & Yes & $\begin{array}{l}\text { Pericardial } \\
\text { adhesion }\end{array}$ & $\begin{array}{r}\text { Complete } \\
\text { healing }\end{array}$ & $\begin{array}{l}\text { Fibrosis } \\
\text { Ulceration }\end{array}$ \\
\hline Dog 6 & 100 & 1 & No & No & $\begin{array}{l}\text { Bleeding, hilar } \\
\text { injury }\end{array}$ & No & No & $\begin{array}{l}\text { Bleeding, hilar } \\
\text { injury }\end{array}$ & $\begin{array}{l}\text { Not } \\
\text { performed }\end{array}$ & Not performed \\
\hline $\operatorname{Dog} 7$ & 100 & 1 & $13 \times 60$ & No & No & No & Yes & $\begin{array}{l}\text { Tracheal } \\
\text { pericardial } \\
\text { adhesion }\end{array}$ & $\begin{array}{r}\text { Complete } \\
\text { healing }\end{array}$ & $\begin{array}{l}\text { Fibrosis } \\
\text { Inflamation }\end{array}$ \\
\hline $\operatorname{Dog} 8$ & 95 & 1 & No & No & Cardiac arrest & No & No & Not performed & Not performed & Not performed \\
\hline Dog 9 & 90 & 2 & $12 \times 60$ & No & $\begin{array}{l}\text { Tension } \\
\text { subcutaneous } \\
\text { emphysema }\end{array}$ & No & No & Not performed & Not performed 1 & Not performed \\
\hline Dog 10 & 110 & 1 & $12 \times 60$ & No & No & No & Yes & $\begin{array}{l}\text { Pericardial } \\
\text { adhesion }\end{array}$ & $\begin{array}{r}\text { Complete } \\
\text { healing }\end{array}$ & Fibrosis \\
\hline Dog 11 & 150 & 2 & $\begin{array}{l}12 \times 60 \\
14 \times 30\end{array}$ & No & Emphysema & No & Yes & $\begin{array}{l}\text { Pericardial } \\
\text { adhesion }\end{array}$ & $\begin{array}{r}\text { Complete } \\
\text { healing }\end{array}$ & $\begin{array}{l}\text { Fibrosis } \\
\text { Inflamation }\end{array}$ \\
\hline Dog 12 & 105 & 1 & $\begin{array}{l}14 \times 30 \\
15 \times 40\end{array}$ & No & No & No & Yes & $\begin{array}{l}\text { Tracheal } \\
\text { pericardial } \\
\text { adhesion }\end{array}$ & $\begin{array}{r}\text { Complete } \\
\text { healing }\end{array}$ & $\begin{array}{l}\text { Fibrosis } \\
\text { Inflamation }\end{array}$ \\
\hline Dog 13 & 80 & 1 & $14 \times 40$ & No & No & No & Yes & $\begin{array}{l}\text { Tracheal } \\
\text { pericardial } \\
\text { adhesion }\end{array}$ & $\begin{array}{r}\text { Complete } \\
\text { healing }\end{array}$ & Fibrosis \\
\hline Dog 14 & 80 & 1 & $12 \times 60$ & No & No & No & Yes & No & $\begin{array}{r}\text { Complete } \\
\text { healing }\end{array}$ & Fibrosis \\
\hline
\end{tabular}

inflammation was present in 4 animals, fibrosis combined with ulceration was present in 1 animal, and cartilage regeneration was noted in 1 animal.

\section{DISCUSSION}

In the preliminary study, TTEP had been shown to be a feasible technique. The preliminary results may provide a novel technique for the study of NOTES in the thoracic cavity.

Transesophageal exploration of the thorax and mediastinum has been reported in an animal survival model and human cadavers. A technical limitation of this method is the need of persistent insufflation of air to maintain positive intraesophageal and mediastinal pressure as well as to perform evaluations and therapy in the thoracic cavity. The use of positive pressure in transesophageal thoracic NOTES procedures carries a substantial risk of barotrauma and tension pneumothorax. ${ }^{2,7}$ We suggest that the thoracic cavity can be evaluated with the present technique using either 1-lung ventilation or intermittent apnea. Furthermore, there is no need to maintain positive mediastinal pressure in the thoracic cavity during NOTES.

One of the major concerns of using the NOTES approach in the thoracic cavity is intraoperative life-threatening emphysema and pneumothorax complications. Our research group has previously suggested prophylactic placement of a chest tube to reduce the incidence of intraoperative tension pneumothorax and to potentially improve operative and perioperative safety. ${ }^{5,6}$ In the present study, we modified our anesthesia technique by placing the long, homemade endotracheal tube approximately $1 \mathrm{~cm}$ above the carina (distal to the incision); this is in contrast to our previous study, which used jet ventilation/conventional proximal endotracheal intubation, with the cuff located immediately below the vocal cords. ${ }^{5,6,8}$ This anesthetic technique provides a relatively safe and stable operative 


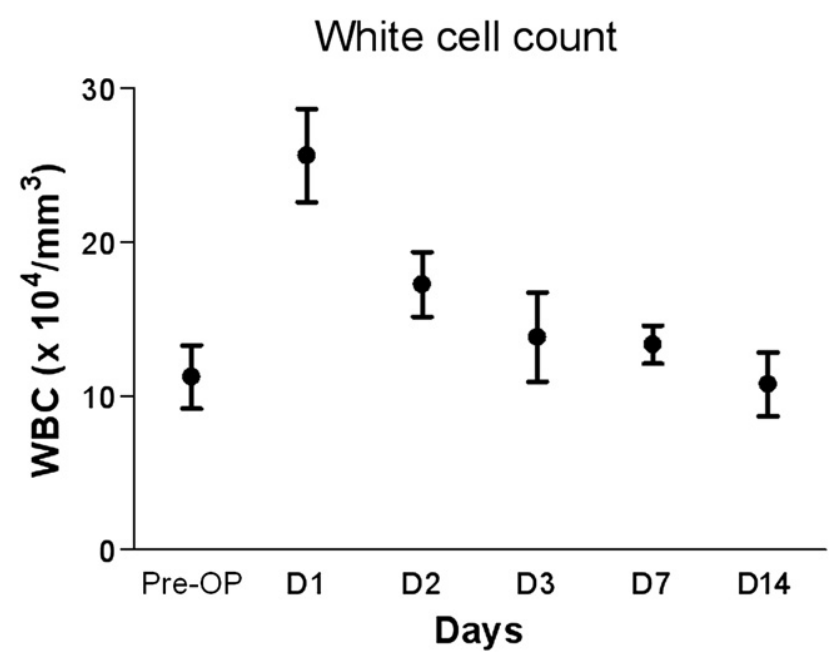

FIGURE 5. Change in white blood cell (WBC) counts in the 11 animals that survived thoracic exploration and pericardial window creation.

environment; no intraoperative air leaks were encountered, even though the last 9 animals had not received prophylactic chest tube placement.

Another major concern in thoracic surgery is mediastinal or thoracic contamination after NOTES. In the present study, we monitored the vital signs and clinical performance of the animals, in addition to focusing on simple inflammatory parameters such as CBC and CRP. The animals that survived did not have any septic symptoms or clinical signs of mediastinitis. An increase in WBC and CRP levels on day 2 suggested that the transtracheal intervention of the thoracic cavity induces an inflammatory response in the thoracic cavity. The increased WBC count returned to normal in 3 days after the operation. CRP levels decreased 7 days after the operation, and in 7 (64\%) of 11 animals, CRP levels returned to normal in 14 days after the operation. Moreover, necropsy revealed a clean mediastinum in all animals. These findings suggest that subclinical infections and inflammatory responses (induced by transtracheal intervention) are almost entirely resolved if the secure closure of tracheal incisions to prevent mediastinal contamination is achieved.

Different techniques for wound closure in NOTES have been proposed. ${ }^{9-11}$ This study demonstrates that the use of a silicone stent for tracheal incision closure facilitated wound healing. However, some complications may be encountered during the operative and postoperative periods. For example, undersized stents may carry a higher risk of air leakage complications, and the discrepancy between the diameter of the airway lumen and the size of the stent may lead to overgrowth of granulation tissue. Accurate pre-sizing of stents by introducing them to the proposed incision site before the creation of a tracheal wound could increase the accuracy in stent

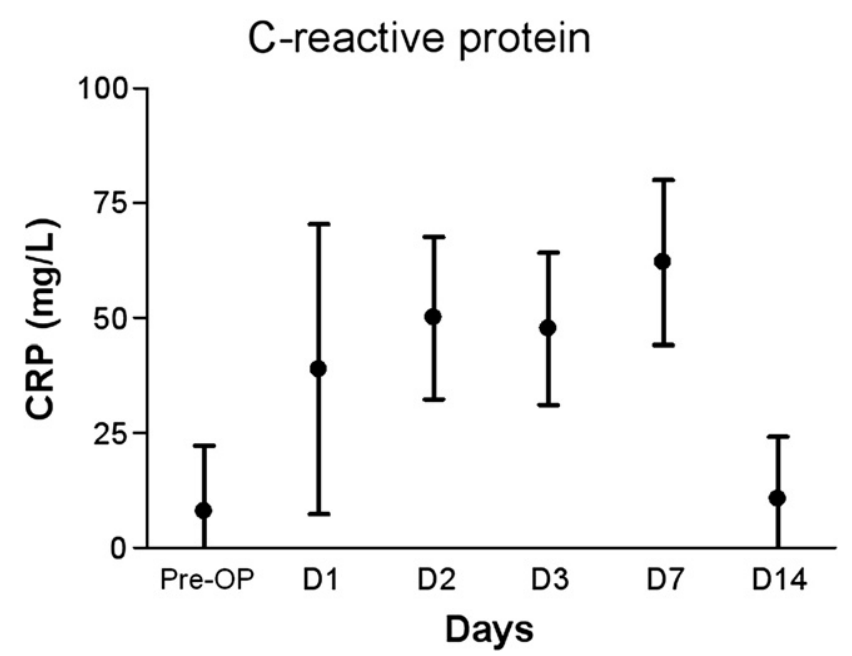

FIGURE 6. C-reactive protein $(C R P)$ levels in the 11 animals that survived thoracic exploration and pericardial window creation.

selection and thus alleviate postoperative complications. In addition, using a longer stent $(>5 \mathrm{~cm})$ and performing the transtracheal NOTES procedure through only 1 tracheal incision could diminish the risk of air leaks after surgery. We believe that more reliable modalities such as synthetic tissue adhesive agents or BioGlue surgical adhesive (CryoLife, Inc, Kennesaw, Ga) may play a role in tracheal wound closure after transtracheal approach procedures. This would avoid airway complications after stent placement. Further studies will be performed in our animal laboratory to clarify the efficacy of BioGlue surgical adhesive on the repair of tracheal wounds after transtracheal thoracic NOTES.

There are several advantages of using the present transtracheal approach to the thoracic cavity. First, the rigid instrument and sequential dilation technique used in this study were a practical and accurate method for tracheal entrance creation. Second, the apical lung region could be directly evaluated without the need of a retroflexed endoscopic maneuver, as reported in previous transesophageal approaches to the thoracic cavity. Third, the silicone stent was easy to apply, efficient for tracheal wound closure, and carried a very low risk of mediastinitis after TTEP. Last, this transtracheal approach allows early feeding compared with previously reported transesophageal approaches.

The mortality rate in the present study was $21 \%$ (3/14 animals). This suggests that this particular approach reflects difficulties that may be encountered when performing the transtracheal NOTES and that there is a learning curve. This approach includes (1) performing the tracheal entrance using a homemade metal knife (with sharp incisions of the tracheal wall, in addition to blunt dissection of mediastinal pleura with a metallic tube used to explore the thoracic cavity), (2) refinement of the endoscopic technique of pericardial window creation (by creating the pericardial window 


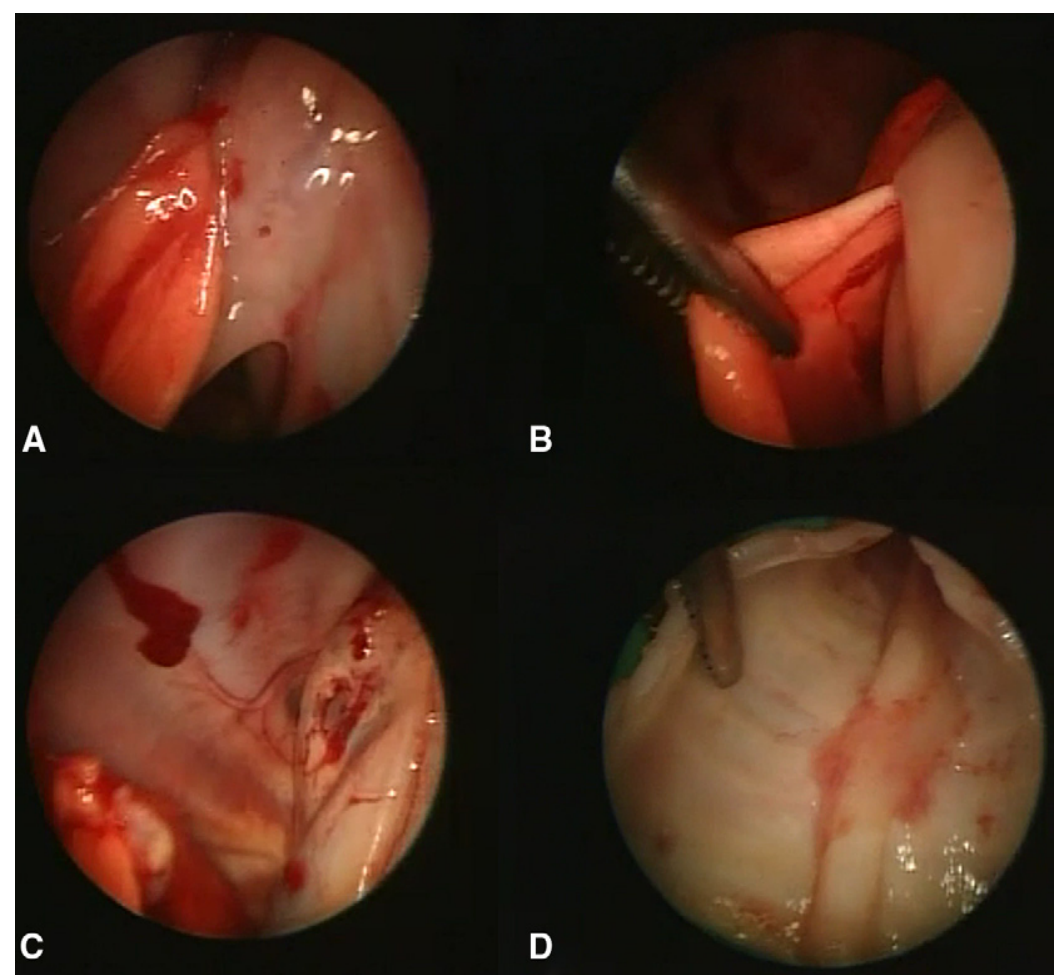

FIGURE 7. A, Autopsy showing mild adhesion over the tracheal incision region. B, Autopsy showing mild adhesion over pericardium. C, Autopsy showing pleural cavity without infection. D, Complete healing of tracheal incision region without leakage.

using a low electrocautery setting to decrease cardiac injury and fibrillation complications), and (3) optimal stent selection for tracheal incision closure (accurate pre-sizing of the stent by introducing it into the proposed incision site before the creation of tracheal wound). We believe that the experi- ence gained through this approach may lead to a decrease in perioperative complications.

The main limitation of our study is its preliminary nature and the fact that the NOTES procedure has been investigated only for minor thoracic procedures such as pleural

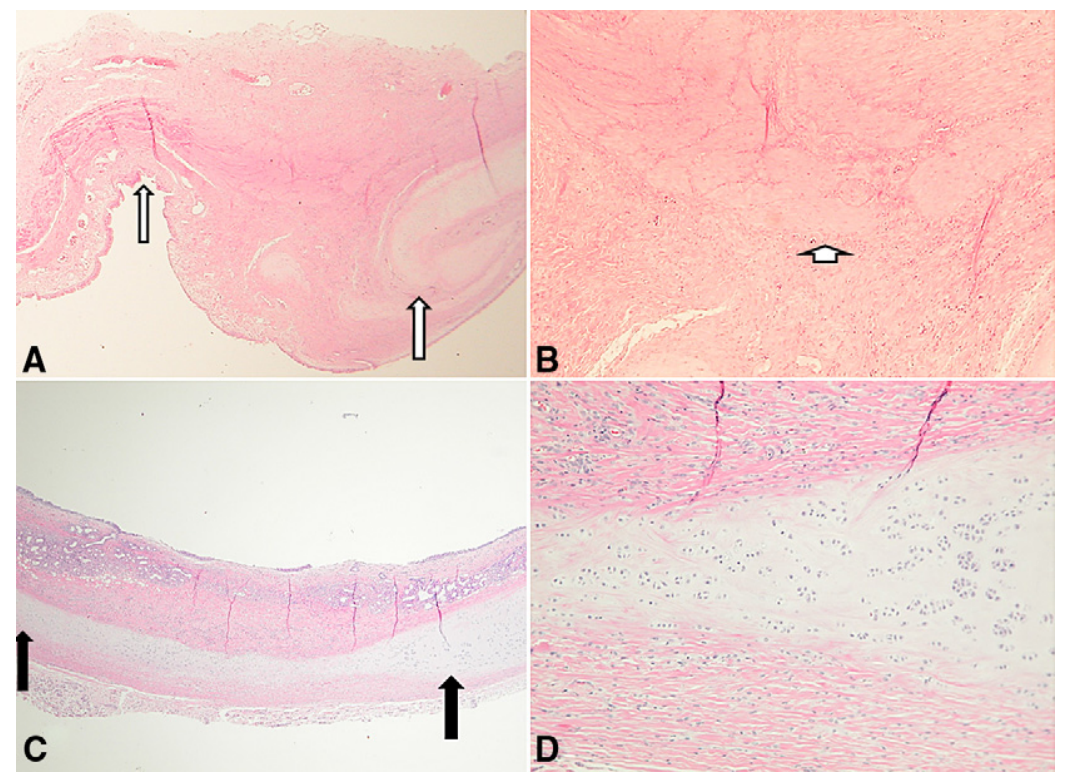

FIGURE 8. A, Histologic examination revealed complete healing of the tracheal wall incision with fibrosis. The white arrows indicated the edges of the tracheal incision. B, High-power view of wound healing with fibrosis (arrowheads). C and D, Histologic examination revealed complete healing of the tracheal wall incision with cartilage regeneration (black arrow). 
examination and the creation of pericardial windows. With a 9-mm tracheal incision and current endoscopic techniques and instrumentation, more complicated thoracic procedures such as surgical lung biopsies would be challenging. Although the feasibility of surgical lung biopsies has been reported in our previous studies, there is a potential difficulty in resecting pulmonary lesions or ligating the lung margin after lung resection via the 9-mm tracheal incision. Another possible limitation of this study is our use of a silicone stent for incision closure. We believe that there were some technical difficulties in selecting an appropriate stent; small stent sizes carry a risk of air leak complications. Better endoscopic techniques and real-time decisions regarding optimal stent sizes are needed to allow the efficient closure of tracheal incision. Another limitation is that only clinical performance and inflammatory parameters before and after NOTES were evaluated and included in the present study. Future NOTES studies of thoracic diseases should focus on hemodynamic conditions during the operation.

In conclusion, we demonstrated that the transtracheal approach to the thoracic cavity using thoracic exploration and pericardial window creation is feasible but carries a risk of major postoperative complications. With continued refinement of anesthesia techniques, endoscopic surgical instrument, and effective and safe devices for closure of tracheal incision sites, transtracheal NOTES could become a potential diagnostic and therapeutic modality for patients with thoracic diseases. At present, comparative studies evaluating transtracheal access procedures (such as NOTES) with conventional video-assisted thoracic surgery in a large animal survival model are mandatory for evaluating the roles of the present technique in the thorax before translation to human applications.

Dr, Yun-Hen Liu had full access to all of the data in the study and takes responsibility for the integrity of the data and the accuracy of the data analysis.

\section{References}

1. Kalloo AN, Singh VK, Jagannath SB, Niiyama H, Hill SL, Vaughn CA, et al. Flexible transgastric peritoneoscopy: a novel approach to diagnostic and therapeutic interventions in the peritoneal cavity. Gastrointest Endosc. 2004;60:114-7.

2. von Delius S, Wilhelm D, Feussner H, Sager J, Becker V, Schuster T, et al. Natural orifice transluminal endoscopic surgery: cardiopulmonary safety of transesophageal mediastinoscopy. Endoscopy. 2010;42:405-12.

3. von Delius S, Meining A. Natural orifice transluminal endoscopic surgery (NOTES). Endoscopy. 2010;42:73-6.

4. Dallemagne B, Perretta S. Natural orifice transluminal endoscopic surgery (NOTES). Endoscopy. 2009;41:895-7.

5. Liu YH, Liu HP, Wu YC, Ko PJ. Feasibility of transtracheal surgical lung biopsy in a canine animal model. Eur J Cardiothorac Surg. 2010;37:1235-6. Epub 2009 Dec 21.

6. Liu YH, Liu HP, Wu YC, Ko PJ. Feasibility of transtracheal thoracoscopy (natural orifice transluminal endoscopic surgery). J Thorac Cardiovasc Surg. 2010; 139:1349-50. Epub 2009 Nov 27.

7. Gee DW, Willingham FF, Lauwers GY, Brugge WR, Rattner DW. Natural orifice transesophageal mediastinoscopy and thoracoscopy: a survival series in swine. Surg Endosc. 2008;22:2117-22.

8. Yang C, Liu HP, Chu Y, Liu YH, Wu CY, Ko PJ, et al. Video. Natural orifice transtracheal evaluation of the thoracic cavity and mediastinum. Surg Endosc. 2010; 24:2905-7. Epub 2010 Apr 7.

9. Romanelli JR, Desilets DJ, Earle DB. Natural orifice transluminal endoscopic surgery gastrotomy closure in porcine explants with the Padlock-G clip using the Lock-It system. Endoscopy. 2010;42:306-10

10. Park PO, Bergström M, Rothstein R, Swain P, Ahmed I, Gomez G, Raju GS. Endoscopic sutured closure of a gastric natural orifice transluminal endoscopic surgery access gastrotomy compared with open surgical closure in a porcine model. A randomized, multicenter controlled trial. Endoscopy. 2010;42:311-7.

11. Hucl T, Benes M, Kocik M, Krak M, Maluskova J, Kieslichova E, et al. A novel double-endoloop technique for natural orifice transluminal endoscopic surgery gastric access site closure. Gastrointest Endosc. 2010;71:806-11. 